\title{
Sorption of organic compounds by organo-zeolites
}

\author{
Magdalena Wołowiec, Barbara Muir, Tomasz Bajda \\ AGH University of Science and Technology, Faculty of Geology, Geophysics and Environmental Protection; \\ al. A. Mickiewicza 30,30-059 Krakow, Poland; e-mail: wołowiecmagdalena@gmail.com
}

(C) 2016 Authors. This is an open access publication, which can be used, distributed and reproduced in any medium according to the Creative Commons CC-BY 4.0 License requiring that the original work has been properly cited.

Organic compounds such as BTEX and PAHs are one of the most common contaminants in water system. These contaminants would take decades to degrade and they have harmful effects on human health (Qin et al. 2008). Several treatment methods have been developed to remove those contaminants from industrial wastewater. They include ion-exchange, filtration, adsorption and the use of various types of sorbents for example zeolites (Kibazohi et al. 2004, Mathur et al. 2007, Aivaliotiet al. 2012, Almeida et al. 2012).

Natural clinoptilolite (Cp) from the Bystré deposit in Slovakia and zeolite Na-X synthesized from fly ash has been modified with a hexadecyltrimethyl ammonium bromide (HDTMA) in amounts of 1.0 and 2.0 of external cation exchange capacity (ECEC) of the zeolites (Szala et al. 2013). The sorption properties of unmodified zeolites and organo-zeolites in terms of aqueous solutions of benzene, ethylobenzene, toluene, $\mathrm{p}$-xylene (BTEX) and their mixtures as well as anthracene, naphthalene, benzo[a]pyrene, dibenzo[a, $\mathrm{h}] \mathrm{anthra-}$ cene (PAHs) and their mixtures at different concentrations were evaluated.

The results showed that the modification of the zeolite $\mathrm{Na}-\mathrm{X}$ and $\mathrm{Cp}$ with HDTMA improves the sorption properties. Modification in the amount of 1.0 ECEC proved to be the best in terms of $\mathrm{p}-\mathrm{xy}$ lene, anthracene, naphthalene, benzo[a]pyrene, dibenzo[a,h]anthracene. On the other hand benzene, ethylobenzene and toluene were adsorbed the most effectively by 2.0 ECEC modification of $\mathrm{Na}-\mathrm{X}$ and $\mathrm{Cp}$. Based on experimental data, the removal efficiencies for BTEX follows the order: p-xylene $>$ toluene $>$ benzene $>$ ethylobenzene, for POHs: dibenzo[a,h]anthracene > benzo[a] pyrene $>$ anthracene $>$ naphthalene. P-xylene and naphtalene were adsorbed in the greatest quantity and benzene and anthracene in the lowest quantity from the mixtures of BTEX and PAHs, respectively. The sorption efficiency depends on the physicochemical properties of the organic compounds (dipole moment, molar mass, molecule structure and the time of the sorption process) as well as natural $\mathrm{Cp}$ and synthetic zeolite $\mathrm{Na}-\mathrm{X}$ properties, such as Si/Al ratio, texture parameters and external cation exchange capacity. With an increasing concentration of the hydrocarbons in the solution the sorption capacity increases (Szala et al. 2015). Natural Cp is a better sorbent than synthetic zeolite Na-X in case of BTEX sorption, while PAHs are adsorbed more effectively by zeolite $\mathrm{Na}-\mathrm{X}$ and its modifications. The mechanism of the sorption consists on the dissolving of the organic compounds into the organic layer of the surfactant (on the zeolites' surface) as well as on the organic compounds' penetration into the mesopores.

The research was financed by the AGH University of Science and Technology statutory grant number 11.11.140.319.

\section{REFERENCES}

Almeida I.L., AntoniosiFilho N.R., Alves M.I., Carvalho BG. \& Coelho NM., 2012. Removal of BTEX from aqueous solution using Moringaoleifera seed cake. Environmental Technology, 33, 1299-1305. 
Aivalioti M., Pothoulaki D., Papoulia P. \& Gidarakos E., 2012. Removal of BTEX, MTBE and TAME from aqueous solutions by adsorption onto raw and thermally treated lignite. Journal of Hazardous Materials, 207-208, 136-146.

Kibazohi O., Yun S.I. \& Anderson W.A., 2004. Removal of Hexane in Biofilters Packed with Perlite and a Peat-Perlite Mixture. World Journal of Microbiology and Biotechnology, 20, 337-343.

Mathur A.K., Majumder C.B. \& Chatterjee S., 2007. Combined removal of BTEX in air stream by using mixture of sugar cane bagasse, compost and GAC as biofilter media. Journal of Hazardous Materials, 148, 64-74.
Szala B., Bajda T., Matusik J., Zięba K. \& Kijak B., 2015. BTX sorption on Na-P1 organo-zeolite as a process controlled by the amount of adsorbed HDTMA. Microporous and Mesoporous Materials, 202, 115-123.

Szala B., Turek P., Bajda T. \& Matusik J., 2013. Optymalizacja procesu syntezy organo-zeolitów. [in:] Szychowski D. (red.), Młodzi dla techniki: wybrane problemy naukowo-badawcze chemii i technologii chemicznej, Politechnika Warszawska, Wydział Budownictwa, Mechaniki i Petrochemii, Sierpc, 109-118.

Qin X.S., Huang G.H. \& Li Y.P., 2008. Risk Management of BTEX Contamination in Ground Water - An Integrated Fuzzy Approach. Ground Water, 46, 5, 755-767. 